\title{
An assessment of the learning environment of early childhood and development education in public schools in Esan west local government area of Edo state, Nigeria
}

\begin{abstract}
The study examined the learning environment as a challenge to the provision of quality early childhood education in public primary schools in Esan West Local Government Area of Edo State, Nigeria. The descriptive survey research design was adopted for this study while a total of 117 teachers were sampled from a population of 468 in all the public primary schools in the locality. Data was collected using random sampling. The instrument used was a questionnaire entitled "Challenges of Early Childhood Education Questionnaire" (CECEQ) while the mean and standard deviation was used to answer the research questions in the study. The findings revealed there are no appropriate school facilities and learning materials in public schools for the teaching of the pre-primary school pupils in Esan West Local Government Area. Hence, it was recommended that the relevant authorities such as the ministry of education, among other development agencies, should facilitate the provision of adequate instructional materials such as toys, books, charts, educational media technology and school facilities such as toilets and game equipment so as to ensure the holistic development of preschoolers.
\end{abstract}

Keywords: learning, environment, early, childhood, development, education, public, schools, Nigeria, instructional media, preschoolers

\section{Introduction}

Education can be regarded as the instruction and training given to an individual to make him or her adjust behaviourally to acceptable norms and mores of his or her immediate environment. Ajala ${ }^{1}$ posits that education is a means of improving the knowledge or intellectual capacity of an individual to make him or her useful to himself/herself and others in the society. This type of education could commence from early childhood. Early childhood or early years in life are the most important to the formation of intelligence, personality and social behaviour of a child. The year before a child reaches kindergarten are among the most critical in his or her life to influence learning. That is why modern societies show serious concern for the education of their young ones by providing needed support to prepare them to succeed later in school. ${ }^{2}$ It is common practice in most societies to make provision for early childhood education programmes of various sorts for children below the official school-going age (usually 6years) mainly to prepare them for education in primary schools. ${ }^{3}$ No country can afford to neglect the education of its children because children are the future assets of their various societies. The Federal Government of Nigeria (FGN) acknowledges the significance of early childhood education in the country and as a result, it was given prominence in the National Policy of Education. ${ }^{4}$ The FGN has further embarked on an integrated approach to early childhood care and development in order to improve the care and support given to young children at the community level and thereby give every Nigerian child a good head start to life. ${ }^{4}$ Ajayi in Ibhaze ${ }^{5}$ documented eight reasons given in support of the provision of affordable, quality programmes of early childcare that are community based, and which are linked to health care and nutrition as part of an integrated approach to meeting the needs of the young child. The reasons include:
Volume 3 Issue I - 2019

\author{
Oluranti Mary Aiwuyo,' Osakue Stevenson \\ Omoera $^{2}$ \\ 'Department of Educational Foundations and Management, \\ Ambrose Alli University, Nigeria \\ 2Department of Theatre and Media Arts,Ambrose Alli University, \\ Nigeria
}

Correspondence: Osakue Stevenson Omoera, Department of Theatre and Media Arts, Faculty of Arts, Ambrose Alli University, Ekpoma, Edo State, Nigeria, Tel +234 80357|4679, Emailomoera@yahoo.com

Received: February 14, 2018 | Published: January 03, 2019 a) from conception of six years of age, children, according to research findings, undergo rapid mental, social and physical development to the extent that by the age of six, their brains would have developed to almost the size of an adult;

b) the convention on the rights of the child stipulates that children have a right to live and develop to their full capacity;

c) moral and social values postulate that through children, societies pass on values and culture from generation to generation;

d) Supporting the development of the child physically and mentally leads to increased enrolment, improves performance and the society generally.

e) provision of early childcare facilities and offer equal opportunities to children from both the privileged and disadvantaged homes.

f) a programme in early childhood development should be used as an entry point for other developmental activities which will benefit the entire community;

g) ECC (Early Child Care) projects should be linked with other developmental activities for women, nutrition, health, water and sanitation.

h) there is a growing demand for better ways of caring for children through an ECC project given the advancement in science and technology which now ensures the survival of many more children, thereby increasing population growth. ${ }^{5}$

In Nigeria, one can not exactly say that the government has committed itself to providing early childhood education to the increasing population of children below the official school-going age. Although, the government recognizes the importance of early 
childhood education in Nigeria by giving it prominence in the National Policy on Education, ${ }^{4}$ but it appears that more needs to be done. The National Policy on Education clearly outlines the objectives of preprimary level to include:

a) Effecting a smooth transition from home to the school;

b) Preparing the child for the primary level of education;

c) Providing adequate care and supervision for the children while their parents are at work, on the farm, in the market places, offices, etc.;

d) Inculcating social norms. Inculcating in the child the spirit of enquiry and creativity through the exploration of nature and the local environment, playing with toys, artistic, music activities, etc.;

e) Teaching numbers, letters, colours, shapes, forms, etc.; and

f) Teaching habits especially good habits.

To achieve these goals, government's strategies for implementation of the pre-primary education programme are as follows:

a) Encouragement of private efforts in provision of pre-primary education;

b) Provision of training programmes for teacher's specialization in Early-Childhood Education.

c) Ensuring the use of the mother-tongue as the medium of instruction in pre-primary schools.

d) Development of the orthography of many Nigeria languages

e) Production of textbooks in Nigerian languages

f) Ensuring the use of play approach in teaching at the pre-primary school level

g) Regulation and control of operation of pre-primary schools.

\section{The school environment}

The education sector in Nigeria is faced with copious challenges. According to Eriba, ${ }^{6}$ the educational system has been in a state of permanent crisis that it has lost quality, efficacy and functionality over the years. Early childhood education in Nigeria is not left out in these crises. A comparative study of universal pre-primary education conducted by Haque ${ }^{7}$ revealed that the condition of pre-primary level of education in Nigeria was very poor. One of such glaring challenges of early childhood education since its introduction in 2007 by the federal government into public primary schools in Nigeria is inadequate and poor learning environment, which is the focus of this study. The school environment can be referred to as all the human and material resources available to the pupils and teachers in the school. The teachers, pupils, other workers in the school, buildings, instructional materials, games equipment and space, toilet facilities, classroom arrangement comprise the school environment. ${ }^{8}$ Ogbonnaya ${ }^{9}$ opines that a nursery school environment should have physical facilities such as swings, slides, merry-go-round, sand boxes, tunnels, balance and other toys. A favourable, conducive and attractive school environment tends to motivate children to learn while an unfriendly environment may discourage learning. The school environment has an important influence on the pre-scholar just as school facilities play important role in the realization of educational goals and objectives. Olaleye ${ }^{10}$ claims that most Nigerian public schools are characterized by the following: a) Inadequate classroom space, furniture, equipment for teaching and learning.

b) Lack of easy access to safe drinking water, hygienic sanitation, and health facilities.

c) Poorly motivated teachers.

d) Use of sub-standard teaching methodologies.

Olaleye further posits that schools characterized by the above are not likely to provide quality education to the children. A similar study on the state of learning environment in Lagos, Nigeria, which was conducted by Okebukola ${ }^{10}$ revealed that learning facilities in the school laboratories were inadequate while some libraries were almost empty. Ndukwe ${ }^{12}$ in another study found that many schools have no adequate games and recreational facilities. Indeed, Akinbote ${ }^{13}$ claimed that many of the primary school teachers are not sufficiently equipped in both the pedagogical and content knowledge of what they are to teach in the schools. Okebukola ${ }^{11}$ while quoting the SAPA report has provided a statistical analysis of the deficiencies in the Nigeria school as follows:

- $12 \%$ of pupils sit on the floor

- $\quad 87 \%$ have overcrowded classrooms

- $\quad 3 \%$ of the schools have no chalkboards

- $38 \%$ of the classrooms have no ceiling

- $77 \%$ of the pupils lack textbooks

- $36 \%$ of the pupils have no writing materials.

Okebukola further claims that, among other things, the unfriendliness of the school environment is induced by:

- inadequacies in classroom space, furniture, equipment and teaching/learning materials;

- poorly motivated teachers;

- $\quad$ use of poor teaching methodologies;

- inadequacy of water, and sanitation facilities in schools; and

- limited community participation in education.

Odiagbe $^{10}$ found out that most instructional materials and resources are not available in public schools for teaching pupils of pre-primary education in Edo State while pointing out the most available instructional materials were the chalk boards and textbooks. Odiagbe also found out that toys were grossly lacking in Edo State public primary schools.

\section{Statement of the problem}

The environment under which learning takes place in many public pre-primary schools in Esan West Local Government Area seem grim as the available classrooms appear to be unappealing in motivating the pre-scholars to learn. Hassan ${ }^{14}$ is of the view that the pre-primary environment and children's experiences in their environment influence their growth, development and welfare. Okebukola ${ }^{11}$ also opines that adequate human and material resources enhance meaningful learning. The National Policy on Education ${ }^{4}$ stipulates that teaching the rudiments of numbers, letters, colours, shapes, and forms should be done through play in pre-primary schools. Teaching through play requires facilities and equipment such as toys, swings, slides, among others. The use of these facilities by children in school could promote 
cooperation, teamwork and socialization amongst them. However, it has been observed that these facilities are not available in public preprimary schools in Edo State as previously noted by Omoera ${ }^{15}$ that in many early childhood education centres in Nigeria, the physical/ learning environment is poorly designed, without ample space, furniture, toys, wholesome pictures and other materials which a child needs for stimulation, exploration and simulation. It is against this background that this study examined the learning environment of early childhood centres in public primary schools in Esan West Local Government Area of Edo State in Nigeria.

\section{Research Questions}

a) Does the quality and qualification of early childhood teachers have any effect on the provision of early childhood education in Esan West Local Government Area of Edo State?

b) Does teacher/ pupil ratio in ECCE centres in public primary schools pose a challenge to the programme?

c) Is the school environment a challenge to the provision of early childhood education?

\section{Methods}

This study covered 468 teachers in 39 public primary schools that have pre-primary section and located in Esan West Local Government Area of Edo State while the descriptive survey research design was used to examine the state of the learning environment for early childhood education in the schools. The simple random sampling technique was used in selecting the sample size of 117 (25\%) of the population. The "challenges of early childhood education questionnaire" (CECEQ) was used for gathering data for the study. The instrument consisted of two sections: (i.e., A \& B) Section A obtained background information such as gender of respondent, educational qualification, name and location of schools, while Section B dwelt on some challenges facing the provision of early childhood education. All items on this section were raised on a four- point rating scale of Strongly Agree (4 points), Agree (3 points), Disagree (2 points) Strongly Disagree (1 point). The instrument was face-validated by experts in Educational
Foundations and Management and Instructional Media at Ambrose Alli University, Ekpoma. The reliability test was ascertained with test re-test method of Spearman Rank Correlation to give 0.82 with an interval of two weeks. This value indicated that the scale was reliable for use in achieving the research objectives. The administration of the instrument was done by the researcher and one trained research assistant. A total of 117 copies of questionnaires were administered to teachers in selected public primary schools while 108 were retrieved and analyzed. The collected data was analyzed using mean and standard deviation.

\section{Results}

Research Question One: Does the quality and qualification of early childhood teachers have any effect on early childhood education in public pre-primary schools Esan West Local Government Area?

Table 1 showed that items 6 and 7 have mean rating of 2.96 and 2.55 with standard deviation of 0.76 and 0.86 which is greater than the cutoff point of 2.50; this implies that teachers in public pre-primary schools lack job motivation and that government does not organize workshops and seminars. However, items 4 and 5 have mean ratings of 2.06 and 1.97 with standard deviation of 0.99 and 0.89 . This implied that unqualified teachers are not some of the problems facing public pre-primary schools and the pre-primary section does not lack adequate teachers. The cluster mean 2.33 and standard deviations of 0.88 implied that the quality and qualification of teachers do not affect the provision of early childhood education in public pre-primary schools in Esan West.

Research Question Two: Does the teacher/pupil ratio in the school pose a challenge to early childhood education?

Table 2 showed that item 8 has mean rating of 2.32 with standard deviation of 0.81 which is lesser than the cutoff point of 2.32. This implied that teacher/pupil ratio is not a challenge to early childhood education in the pre-primary section of public primary schools. Research Question Three: Is the school learning environment a challenge to the provision of early childhood education?

Table I Mean ratings and standard deviations of respondents on the quality and qualification of early childhood education teachers

\begin{tabular}{|c|c|c|c|c|c|c|c|c|}
\hline Item & Item description & SA & $\mathbf{A}$ & D & SD & Mean & $\begin{array}{l}\text { Standard } \\
\text { deviation }\end{array}$ & Decision \\
\hline 4 & $\begin{array}{l}\text { Unqualified early childhood education teachers are some of the } \\
\text { problems faced in my school }\end{array}$ & 15 & 12 & 46 & 35 & 2.06 & 0.99 & Rejected \\
\hline 5 & The pre-primary section in my school lacks adequate teachers & 10 & 11 & 53 & 34 & 1.97 & 0.89 & Rejected \\
\hline 6 & Lack of teacher's motivation & 23 & 64 & 15 & 6 & 2.96 & 0.76 & Accepted \\
\hline \multirow[t]{2}{*}{7} & Government does not organize workshops and seminars & 15 & 41 & 40 & 12 & 2.55 & 0.86 & Accepted \\
\hline & Cluster mean/standard Deviation & & & & & 2.33 & 0.883 & \\
\hline
\end{tabular}

Table 2 Mean ratings and standard deviations of respondents on teacher/pupils ratio as a challenge

\begin{tabular}{|c|c|c|c|c|c|c|c|c|}
\hline Item & Item description & SA & $\mathbf{A}$ & D & SD & Mean & Standard deviation & Decision \\
\hline 8 & Teacher/pupil ratio in my school is inappropriate & 10 & 29 & 55 & 14 & 2.32 & 0.81 & Rejected \\
\hline
\end{tabular}

Table 3 Mean Rating and Standard Deviations of respondents on the school environment as a challenge to early childhood education, Table 3 showed that items 9,10,11,12 and 13 have mean ratings of $3.20,3.35,3.41,3.47$, and 3.38 with standard deviations of 0.62 , $0.53,0.51,0.52$ and 0.63 which are higher than the cutoff point of 2.50. This implied that the pre-primary section lacked appropriate instructional materials, toys for learning, modern toilet facilities, adequate water supply, game equipment and space. The cluster mean of 3.36 and standard deviation of 0.56 implied that the school learning environment is a challenge to the provision of early childhood education in Esan West Local Government Area. 
Table 3 Mean rating and standard deviations of respondents on the school environment as a challenge to early childhood education

\begin{tabular}{|c|c|c|c|c|c|c|c|c|}
\hline Item & Item description & SA & $\mathbf{A}$ & D & SD & Mean & Standard deviation & Decision \\
\hline 9 & The school lacks appropriate instructional materials & 33 & 65 & 9 & 1 & 3.2 & 0.62 & Accepted \\
\hline 10 & Lack of toys for learning & 41 & 64 & 3 & - & 3.35 & 0.53 & Accepted \\
\hline 11 & Lack of modern toilet facilities & 45 & 62 & 1 & - & 3.41 & 0.52 & Accepted \\
\hline 12 & Lack of adequate water supply & 52 & 55 & 1 & - & 3.47 & 0.52 & Accepted \\
\hline \multirow[t]{2}{*}{13} & Lack of game equipment and space & 49 & 52 & 6 & 1 & 3.38 & 0.63 & Accepted \\
\hline & Cluster mean/standard Deviation & & & & & 3.36 & 0.56 & \\
\hline
\end{tabular}

\section{Discussion}

The findings of this study revealed that the quality and qualification of teachers do not affect the provision of early childhood education in public primary schools. The reason being that, the least qualified teachers in the public schools were the NCE holders which is the minimum qualification required in the pre-primary and primary levels of education in Nigeria. Most teachers employed in the public primary schools across Edo State are holders of Nigeria Certificate in Education (NCE) and University graduate teachers. This finding, however, contradicts the observation of Sooter ${ }^{16}$ that teacher quality in Nigerian early childhood institutions is low. Research question two revealed that teacher/pupil ratio in the pre-primary sections of public primary schools in Esan West Local Government Area does not constitute a challenge to the provision of early childhood education. This may be due to the low enrolment of pupils as a result of the proliferation of private pre-primary schools. The analysis of research question three revealed that the school learning environment is a challenge to early childhood education as there are no appropriate learning materials and other relevant facilities to aid pupils' learning. This finding is in line with that of Odiagbe ${ }^{17}$ which holds that most instructional materials and resources are not available in schools for teaching pupils of pre-primary education in Edo State. The finding also corroborates that of Omoera ${ }^{15}$ that in many early childhood education centres in Nigeria the physical/learning environment is poorly designed without ample space, furniture, toys, wholesome pictures and other materials. The situation in some of the schools visited was disheartening as feces littered in parts of the school premises due to lack of sanitary materials and toilets while instructional materials were not available. The provision of a supportable learning environment for public pre-primary school pupils in Esan West by government is urgently required to avoid an abysmal failure of early childhood education in the local government area in particular and in Edo State in general.

\section{Conclusion}

The study established that the pre-primary section in public primary schools in Esan West Local Government Area of Edo State lacked adequate instructional materials and school facilities. Instructional materials such as musical instruments, television and radio sets, counters/ abacus, pictures and cartoons and toys that could aid learning in early years were unavailable while facilities such as game equipment, adequate water supply and modern toilets were grossly inadequate.

\section{Recommendation}

The government should provide instructional materials and other school facilities such as modern toilet facilities, adequate water supply, game equipment, etc., in order to create a safe and enabling environment for the teaching of preschoolers in public schools. A tolerable learning environment for the Nigerian child will no doubt engender effective teaching and learning, thereby allowing a child's to develop his or her fullest potential at the foundation levels of education.

\section{Acknowledgments}

None.

\section{Conflicts of interest}

The author declares that there are no conflicts of interest.

\section{References}

1. Ajala EO. Stakeholders' strategies for effective implementation of nursery education in Enugu State. Nigerian Journal of OMEP. 2013;10(1):1-9.

2. Ejieh MUC. Pre-primary education in Nigeria: Policy implementation and problems. Elementary Education Online. 2006;5(1):58-64.

3. Obidike IV. Towards effective early childhood care and education programme in Nigeria. Journal of Teacher Perspective. 2012;6(3):507513

4. Federal Republic of Nigeria. National policy on education. Lagos: NERDC Press; 2013. 34 p.

5. Ibhaze FO. Issues and challenges of implementation of early childhood education in Nigeria. International Journal of Scientific and Research Publications. 2016;6(5):176-179.

6. Eriba JO. Nigeria at Fifty: An appraisal of her Educational system. A paper presented at the $5^{\text {th }}$ Annual National Conference of the School of Education College of Education Katsina-Ala on the $11^{\text {th }}$ August 2011.

7. Haque MN, et al. Universal pre-primary education: A comparative study. American Journal of Educational Research. 2013;1(1):31-36.

8. Aiwuyo OM. An assessment of the challenges of early childhood education in primary schools in Esan West Local Government Area, Edo State. Unpublished Thesis: National Open University of Nigeria; 2017.

9. Ogbonnaya NO. Principles and applications of educational policies in Nigeria. Enugu: University Trust Publishers; 2010. 255 p.

10. Olaleye FO. Creating a friendly school learning environment for Nigerian children. European Scientific Journal. 2009;8(8):138-147.

11. Okebukola P. The child-friendly school initiative as a new dimension in Educational Development in Nigeria. A paper presented at the $7^{\text {th }}$ Annual Conference on Education development in Lagos State. 2000.

12. Ndukwe PN. School and teacher factors, as determinants of classroom material resources utilization in pre-primary schools in Lagos State. Unpublished Thesis, Enugu: University of Ibadan. 2002. 112 p. 
13. Akinbote $\mathrm{O}$. The Nigerian primary school teachers: Angels of instruction or devils of destruction? Nigerian Journal of Education Philosophy. 2001;8(1):35-40.

14. Hassan A. Public policy in early childhood education and care International Journal of Childcare and Education Policy. 2007;1(1):1223.

15. Omoera OS. Repositioning early childhood education in Nigeria: The children's theatre approach. Preschool Education Today: Theory and Practice. 2013;5(7):60-67.
16. Sooter T. Early childhood education in Nigeria: Issues and problems. Journal of Education and Social Research. 2003;3(5):173-179.

17. Odiagbe SI. Early childhood and development education in public schools: Is it a Mirage or a reality in Edo State? Studies in Education. 2016;16(1):40-50 